\title{
The predictive and prognostic potential of plasma telomerase reverse transcriptase (TERT) RNA in rectal cancer patients
}

Enrica Rampazzo ${ }^{1}$, Paola Del Bianco ${ }^{2}$, Roberta Bertorelle ${ }^{3}$, Caterina Boso ${ }^{4}$, Alessandro Perin ${ }^{5}$, Giovanna Spiro $^{5}$, Francesca Bergamo ${ }^{6}$, Claudio Belluco ${ }^{7}$, Angela Buonadonna ${ }^{8}$, Elisa Palazzari ${ }^{9}$, Sara Leonardi ${ }^{6}$, Antonino De Paoli ${ }^{9}$, Salvatore Pucciarelli ${ }^{5}$ and Anita De Rossi ${ }^{*, 1,3}$

${ }^{1}$ Section of Oncology and Immunology, Department of Surgery, Oncology and Gastroenterology, University of Padova, Via Gattamelata 64, Padova 35128, Italy; ${ }^{2}$ Clinical Trials and Biostatistic Unit, Istituto Oncologico Veneto (IOV)-IRCCS, Via Gattamelata 64, Padova 35128, Italy; ${ }^{3}$ Immunology and Molecular Oncology Unit, IOV- IRCCS, Via Gattamelata 64, Padova 35128, Italy; ${ }^{4}$ Radiotherapy and Nuclear Medicine Unit, IOV-IRCCS, Via Gattamelata 64, 35128 Padova, Italy; ${ }^{5}$ Section of Surgery, Department of Surgery, Oncology and Gastroenterology, Via Giustiniani 1, University of Padova, Padova 35128, Italy; ${ }^{6}$ Medical Oncology Unit 1, IOV-IRCCS, Via Gattamelata 64, Padova 35128, Italy; ${ }^{7}$ Department of Surgical Oncology, Centro di Riferimento Oncologico (CRO)-IRCCS, Aviano, Italy; ${ }^{8}$ Department of Medical Oncology B, CRO-IRCCS, Aviano, Italy and ${ }^{9}$ Radiation Oncology, CRO-IRCCS, Aviano, Italy

Background: Preoperative chemoradiotherapy (CRT) followed by surgery is the standard care for locally advanced rectal cancer, but tumour response to CRT and disease outcome are variable. The current study aimed to investigate the effectiveness of plasma telomerase reverse transcriptase (TERT) levels in predicting tumour response and clinical outcome.

Methods: 176 rectal cancer patients were included. Plasma samples were collected at baseline (before CRT = T0), 2 weeks after CRT was initiated (T1), post-CRT and before surgery (T2), and 4-8 months after surgery (T3) time points. Plasma TERT mRNA levels and total cell-free RNA were determined using real-time PCR.

Results: Plasma levels of TERT were significantly lower at T2 $(P<0.0001)$ in responders than in non-responders. Post-CRT TERT levels and the differences between pre- and post-CRT TERT levels independently predicted tumour response, and the prediction model had an area under curve of 0.80 (95\% confidence interval (Cl) 0.73-0.87). Multiple analysis demonstrated that patients with detectable TERT levels at T2 and T3 time points had a risk of disease progression 2.13 (95\% Cl 1.10-4.11)-fold and 4.55 (95\% Cl 1.48-13.95)-fold higher, respectively, than those with undetectable plasma TERT levels.

Conclusions: Plasma TERT levels are independent markers of tumour response and are prognostic of disease progression in rectal cancer patients who undergo neoadjuvant therapy.

The identification of specific, sensitive and non-invasive approaches that facilitate early diagnosis, predict cancer recurrence and gauge the effectiveness of cancer therapy is an important target in oncology. As the dynamic nature of the circulatory system and its constituents may reflect the host's pathological status, liquid biopsies, including analysis of circulating tumour cell-free DNA and RNA released from tumour cells, are being investigated as potential sources of non-invasive markers that could facilitate

*Correspondence: Professor A De Rossi; E-mail: anita.derossi@unipd.it 
formulating early cancer diagnosis, making therapeutic decisions and monitoring disease progression (Gingras et al, 2015; Lewis et al, 2015; Alix-Panabières and Pantel, 2016).

The circulating mRNAs that encode telomerase reverse transcriptase (TERT) may be of particular interest in this setting. TERT, the catalytic protein of the telomerase complex that synthetises de novo telomere sequences using the internal telomerase RNA template (TR), extends telomeres at the ends of eukaryotic chromosomes, thus preventing cell senescence and death (Blackburn et al, 2006). Although TR has broad tissue distribution and is constitutively present in normal and tumour cells, TERT expression, which is usually repressed in normal somatic cells and is essential for unlimited replicative potential, has a critical role in tumour formation and progression (Hanahan and Weinberg, 2011). Several recent studies have demonstrated that TERT mRNA level in tumours is an independent prognostic marker in various types of cancers (Giunco et al, 2015), including colorectal cancer (Bertorelle et al, 2013, 2014). Notably, circulating TERT mRNA has been identified in patients with gastric (Tani et al, 2007; Kang et al, 2013), prostatic (March-Villalba et al, 2012), lung (Miura et al, 2006), and colorectal cancers (Lledó et al, 2004; Terrin et al, 2008). Evidence that circulating TERT mRNA levels reflect TERT mRNA levels in tumours (Miura et al, 2006; Terrin et al, 2008; Deblakshmi et al, 2015) supports the concept that circulating cell-free TERT mRNA may be a promising non-invasive biomarker in clinical practice.

Worldwide, colorectal cancer is the third most common cancer in men and the second in women. It accounts for over $9 \%$ of all cancers, with an estimated 1.4 million cases occurring in 2012 (Torre et al, 2016). Approximately $30 \%$ of colorectal cancer arise in the rectum (Siegel et al, 2014) and preoperative chemoradiotherapy (CRT) is the standard care for locally advanced rectal tumours, but response to CRT varies from complete to none (Sauer et al, 2004; Bosset et al, 2006; Gerard et al, 2006; Roh et al, 2009). Although the nonresponder patients are exposed to inefficient, toxic therapy, patients with a pathological complete response to CRT show better outcomes compared with non-responders (Maas et al, 2010). Although identifying predictors of tumour response has become crucially important, biomarkers that are able to predict tumour response to CRT and foresee disease outcomes are for the time being unavailable (Spolverato et al, 2011; Lim et al, 2015).

Predicting tumour response to therapy has important clinical implications, not only for facilitating the selection of patients who will respond to CRT but also for modifying chemoradiation regimens and surgical procedures. A prognostic biomarker could also help to identify patients at higher risk of disease progression or recurrence, who would benefit from adjuvant therapy and intensive surveillance.

In a retrospective pilot study, conducted in a small group of rectal cancer patients who underwent CRT followed by surgery, we evaluated circulating TERT mRNA plasma levels before and after CRT. Study results showed that TERT levels fell significantly in the responders, but they remained unvaried or even rose in the non-responders, thus suggesting that plasma TERT mRNA can be a marker of tumour response to CRT (Pucciarelli et al, 2012). This result, together with evidence of the prognostic role of TERT mRNA levels in tumour cells of patients with colorectal cancer (Bertorelle et al, 2013) and the finding that circulating TERT levels reflect those in cancer specimens (Terrin et al, 2008) prompted us to assess the role of circulating TERT mRNA as a predictive marker of response to neoadjuvant therapy and a prognostic marker of disease progression in a larger number of patients with rectal cancer.

\section{PATIENTS AND METHODS}

Patients and treatment characteristics. This study was conducted in patients with primary adenocarcinoma of the rectum, who were enrolled in a prospective study and underwent CRT followed by total mesorectal excision at the Surgery Section, Department of Surgery, Oncology and Gastroenterology, University of Padova (87 patients), and at the Centro di Riferimento Oncologico, Aviano (89 patients). The patients' work-up included clinical history, physical examination, colonoscopy, complete blood cell count, pelvic magnetic resonance imaging, chest/abdomen computed tomography scan and carcinoembryonic antigen (CEA) determination. The criteria for receiving neoadjuvant CRT were as follows: biopsyproven adenocarcinoma of the mid-low rectum (up to $11 \mathrm{~cm}$ from the anal verge), clinically staged as Tumour, Node, Metastasis (TNM) II-III or stage I low-lying rectal cancer requiring abdominoperineal resection and an Eastern Cooperative Oncology Group performance status score of $0-2$. Patients received a total dose of radiotherapy $\geqslant 45 \mathrm{~Gy}$ (median $50.40 \mathrm{~Gy}$, range $45-54 \mathrm{~Gy}$ ) delivered with high-energy photons $(\geqslant 6 \mathrm{MV})$ at conventional fractionation (1.8 Gy per day, 5 sessions per week) and fluoropyrimidine-based chemotherapy.

Peripheral blood samples were drawn from patients at the study's time point, that is, at diagnosis, pre-CRT, (T0), 2 weeks after initiating CRT (T1), post-CRT and before ( -2 to 0 day) surgery (T2) and 4-8 months after surgery (T3). Plasma samples were obtained from peripheral blood by centrifugation at 3000 r.p.m. for $10 \mathrm{~min}$ and aliquots were stored at $-80^{\circ} \mathrm{C}$ until they were analysed. Only patients with plasma samples at $\geqslant 3$ time points (134 patients) or plasma samples at least at T0 and T2 time points (42 patients), for a total of 176 patients, were included in this study and represent the study group. The local Ethics Committees approved the study and each patient signed the informed consent (protocol number 35333/AO/15).

Evaluation of pathologic tumour response. Pathologists from the institutions involved in the study, unaware of patients' outcomes, assessed the surgical specimens. The tumours were pathologically staged according to the American Joint Committee on Cancer that established TNM staging system (Edge and Compton, 2010; Amin et al, 2017). The tumour response to CRT was assessed in surgical specimens by pathological examination based on Mandard's tumour regression grading (TRG) system (Mandard et al, 1994). Tumour regression grading was defined as follows: no residual cancer cells $=$ TRG1; rare residual cancer cells $=$ TRG2; fibrosis outgrowing residual cancer cells $=$ TRG3; residual cancer cells outgrowing fibrosis =TRG4; absence of regressive changes $=$ TRG5. In accordance with previous studies (Beddy et al, 2008; Pucciarelli et al, 2012), this classification was further simplified by considering patients classified as TRG1 and 2 as responders, and those with TRG 3 to 5 as non-responders.

RNA extraction from plasma samples. RNA was extracted from plasma samples as previously described (Terrin et al, 2008; Pucciarelli et al, 2012), with some modifications to improve RNA extraction. Each plasma sample $(500 \mu \mathrm{l})$ was slowly thawed on ice and then mixed with $1500 \mu$ l of Trizol LS reagent (Thermo Fisher Scientific, Waltham, MA, USA) in a $15 \mathrm{ml}$ conical tube. After $5 \mathrm{~min}$ of incubation at room temperature, $400 \mu \mathrm{l}$ of chloroform were added to each sample, followed by $15 \mathrm{~s}$ of shaking and $15 \mathrm{~min}$ of incubation on ice. The samples were then centrifuged at $12000 \mathrm{~g}$ for $30 \mathrm{~min}$ at $4{ }^{\circ} \mathrm{C}$ in a J-25 Centrifuge (Beckman Coulter, Brea, CA, USA). The upper aqueous phase was transferred into a new $2 \mathrm{ml}$ tube, mixed with $1 \mathrm{ml}$ of isopropyl alcohol and $15 \mu \mathrm{l}$ of Glycogen $\left(5 \mathrm{mg} \mathrm{ml}^{-1}\right.$, Thermo Fisher Scientific) and incubated overnight at $-20^{\circ} \mathrm{C}$ to allow for RNA precipitation. The samples were then centrifuged at $12000 \mathrm{~g}$ for $1 \mathrm{~h}$ at $4{ }^{\circ} \mathrm{C}$ in a microcentrifuge (Biofuge Stratos, Hareaus Instruments, Thermo Fisher Scientific). The supernatant was removed and the RNA pellet was washed with $1 \mathrm{ml} 75 \%$ ethanol by centrifugation at $12000 \mathrm{~g}$ for $15 \mathrm{~min}$ at $4{ }^{\circ} \mathrm{C}$. The ethanol was removed, the RNA pellet was dried for $5 \mathrm{~min}$ at room temperature and then 
resuspended in $20 \mu \mathrm{l}$ of RNase-free water. RNA was reversetranscribed into cDNA using the SuperScript TM III RNase reverse trancriptase assay (Thermo Fisher Scientific) in a final volume of $80 \mu \mathrm{l}$, according to the manufacturer's instructions.

Quantification of circulating TERT mRNA. The expression of TERT transcripts in the plasma samples was quantified by realtime PCR, as previously described (Terrin et al, 2008), with some modifications. In particular, a new primer pair was designed in order to reduce the length of the amplified product, thus improving detection of the cDNA target sequence (El-Hefnawy et al, 2004; Spornraft et al, 2014). Primers AT1 (5'-CGGAAGAGTGTCTGGAGCAA-3 ${ }^{\prime}$ ) and AT2b (5'-CGCAGCTGCACCCTCTTCA- $3^{\prime}$ ) were designed on exon 3 and 4 , respectively; they bind to nucleotide sequences located upstream of the RT motif 1 on the TERT gene allowing amplification of all TERT transcripts producing an amplified product of $68 \mathrm{bp}$. The fluorogenic probe AT (FAM 5'-TTGCAAAGCATTGGAATCAGACAGCAC-3' TAMRA) recognises the sequence located inside the product amplified by AT1/AT2b. The PCR was performed using an ABI prism 7900 Sequence Detection System (PE Applied Biosystems, Foster City, CA, USA) in $50 \mu \mathrm{l}$ of mixture containing $25 \mu \mathrm{l} 2 \mathrm{X}$ TaqMan Universal (PE Applied Biosystems), $100 \mathrm{nM}$ of fluorogenic probe, $600 \mathrm{nM}$ of primer AT1, $900 \mathrm{nM}$ of primer AT2b and $10 \mu \mathrm{l}$ of cDNA sample. After $2 \mathrm{~min}$ at $50^{\circ} \mathrm{C}$ to allow the uracil $\mathrm{N}$-glycosylase to act and a denaturation step lasting $10 \mathrm{~min}$ at $95^{\circ} \mathrm{C}, 50$ cycles were run, each consisting of $30 \mathrm{~s}$ at $95^{\circ} \mathrm{C}, 30 \mathrm{~s}$ at $60^{\circ} \mathrm{C}$ and $30 \mathrm{~s}$ at $72{ }^{\circ} \mathrm{C}$. Each sample was run in triplicate and the mean $\mathrm{Ct}$ values were plotted against the standard TERT reference curve, which was generated with serial fivefold dilutions of the TERT amplicon, as previously described (Terrin et al, 2007). TERT values were estimated per $\mathrm{ml}$ according to the $\mathrm{X} 8 \mathrm{X} 2$ conversion factor and then expressed as TERT copies per $\mathrm{ml}$.

Ten microlitres cDNA from each sample were also amplified for the housekeeping hypoxantin-guanine phosphoribosyl transferase 1 (HPRT1) gene (Terrin et al, 2008; Pucciarelli et al, 2012). The forward primer HPRT1for (5'-TCAGGCAGTATAATCCAAAGATGGT-3') was designed between exons 4 and 5, and the reverse primer HPRT1rev (5'-CTTCGTGGGGTCCTTTTCAC-3') was designed on exon 6 , generating a cDNA amplified product of $64 \mathrm{bp}$. The fluorogenic probe (VIC 5'-AAGGTCGCAAGCTT-3' MGBNFQ) recognises the sequence located within the products amplified by HPRT1for/HPRT1rev. PCR was performed using an ABI prism 7900 Sequence Detection System (PE Applied Biosystems) in $50 \mu \mathrm{l}$ of mixture containing $25 \mu \mathrm{l} 2 \times$ TaqMan universal master mix (PE Applied Biosystems), $200 \mathrm{nM}$ of fluorogenic probe, $900 \mathrm{nM}$ of primer HPRT1for and HPRT1rev and $10 \mu \mathrm{l}$ of cDNA sample. The thermal cycler profile consisted of $2 \mathrm{~min}$ at $50^{\circ} \mathrm{C}, 10 \mathrm{~min}$ at $95^{\circ} \mathrm{C}$ and then 45 cycles were run, each consisting of $30 \mathrm{~s}$ at $95^{\circ} \mathrm{C}, 30 \mathrm{~s}$ at $60^{\circ} \mathrm{C}$ and $30 \mathrm{~s}$ at and $72^{\circ} \mathrm{C}$. Each sample was run in triplicate and the mean $\mathrm{Ct}$ values were plotted against the standard HPRT1 reference curve, prepared using serial dilutions of the HPRT1 amplicon, as previously described (Terrin et al, 2008). TERT values were expressed as TERT copies per $10^{3}$ HPRT1 copies.

Quantification of circulating cell-free RNA. To determine the amount of cell-free RNA in plasma samples, a calibration weight standard curve was constructed, as previously described (Terrin et al, 2008). Briefly, $1 \mu \mathrm{g}$ of RNA (TaqMan Control Genome RNA $50 \mathrm{ng}^{-1} \mathrm{l}^{-1}$, Applied Biosystems) was retrotranscribed into cDNA and fivefold serially diluted in TE buffer (Tris $\mathrm{HCl} 10 \mathrm{mM}, \mathrm{pH}$ 7.6, EDTA $1 \mathrm{mM}, \mathrm{pH}$ 8.0) from 5000 to $32 \mathrm{pg}^{-1}$. Ten microlitres of cDNA were collected from each dilution and amplified for the housekeeping gene HPRT1 with the HPRT1for/HPRT1rev primer pair. All samples were analysed in triplicate and the resulting median $\mathrm{Ct}$ values were plotted against the calibration weight curve.
The values of cell-free RNA were estimated per $\mathrm{ml}$ using the conversion factor X $8 \times 2$ and expressed as $\mathrm{pg} \mathrm{ml}^{-1}$.

Statistical analysis. The data were analysed using SAS 9.4 (SAS Institute, Cary, NC, USA). The clinical and demographic characteristics of the rectal cancer patients were described according to median and interquartile range (IQR) for quantitative data, and frequencies and percentages for categorical data, and their relationship with tumour response to neoadjuvant therapy was assessed using the Kruskal-Wallis test and the $\chi^{2}$-test or Fisher's exact test, as appropriate.

The distribution of marker (TERT, RNA and CEA) levels between responder and non-responder groups was assessed at each time point using the Kruskal-Wallis test and the pairwise comparisons between each time point within each group was assessed by the Wilcoxon's signed-rank test. A receiver operator characteristic (ROC) curve was constructed to estimate the specificity and sensitivity of the best cut-off value discriminating between responders and non-responders. Univariate logistic regression models were used to evaluate the relationship between the potential clinical and biological predictors and the tumour response; variables statistically significant at $10 \%$ level were entered into a multiple logistic model to backward select predictors that were independently associated with the response to neoadjuvant therapy. The diagnostic performance of the final multiple model was estimated with the area under curve (AUC).

The time-to-event analysis by Kaplan-Meier and the univariate Cox proportional hazard models provided the estimates of the probability of disease progression. Progression-free survival (PFS) was calculated from the date of surgery to the occurrence of relapse/progression or death. Patients who did not develop any event during the study period were censored at the date of last observation. The PFS probability was compared among strata using the log-rank test and the 5-year PFS was reported with the 95\% confidence interval (CI). Separate multiple Cox proportional hazard models were developed with biological markers drawn after CRT, before surgery (T2), and 4-8 months after surgery (T3), together with clinical factors resulting significant at univariate analysis. No deviation from the proportional hazards assumption was found using the numerical methods of Lin et al (1993). All the statistical tests used a two-sided 5\% significance level and association measures were provided with their 95\% CI.

\section{RESULTS}

Demographic and clinical characteristics of patients. The characteristics of the 176 patients who met the inclusion criteria are summarised in Supplementary Table 1. According to the simplified TRG classification, 74 patients (48 TRG1 and 26 TRG2) were considered responders and 102 patients (74 TRG3, 23 TRG4 and 5 TRG5) were non-responders. The responders were significantly older $(P=0.0106)$ and had an earlier clinical stage $(P=0.0393)$ than non-responders. No differences were found in any of the other baseline characteristics (Supplementary Table 1).

Association between TERT levels and tumour response to neoadjuvant therapy. Circulating cell-free TERT mRNA (henceforth TERT) was determined in 175 patients at T0 and in 153 patients at T2 time point; at T1, samples were available from 117 patients. At T0, TERT levels did not differ between responders and non-responders: the median (IQR) was $153(0-325)$ copies per $\mathrm{ml}$ in responders and $137(0-350)$ copies per $\mathrm{ml}$ in non-responders $(P=0.472)$ (Figure 1A). At T1, a fall in TERT levels, although not significant, was detected in responders, being TERT level $11(0$ 204) copies per $\mathrm{ml}(P=0.285)$, but not in non-responders, being TERT level $132(0-208)$ copies per $\mathrm{ml}(P=0.996)$. At T2, the TERT levels were significantly lower in the responders with respect 
A

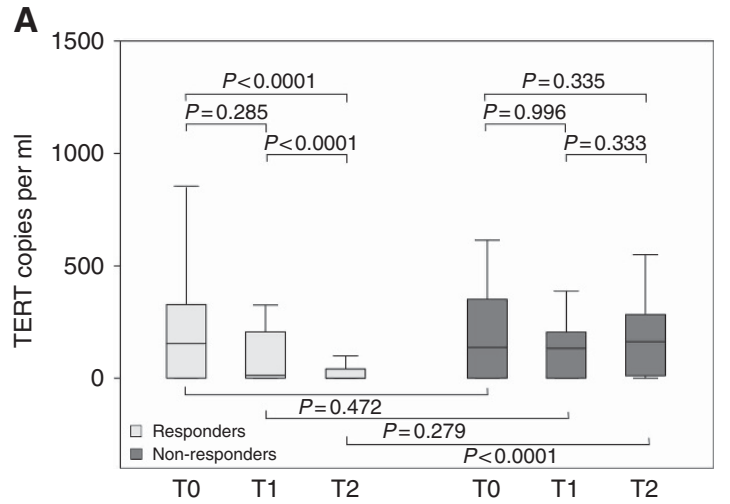

C

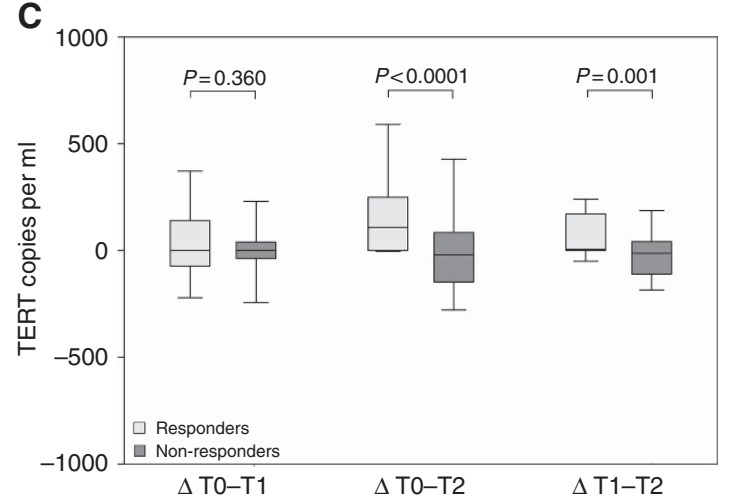

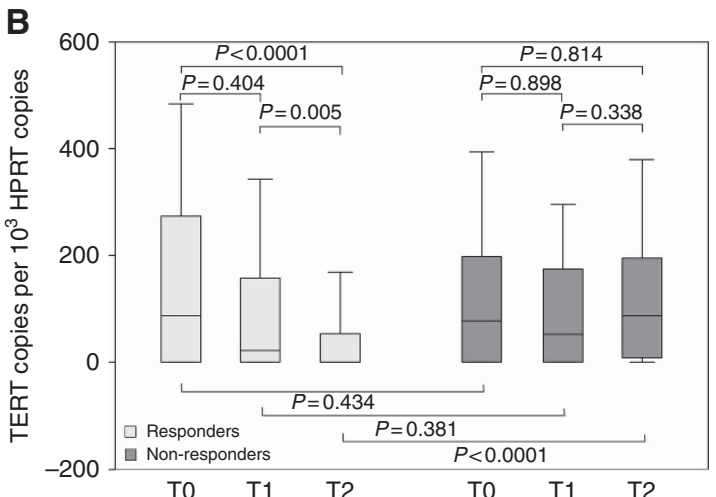

D

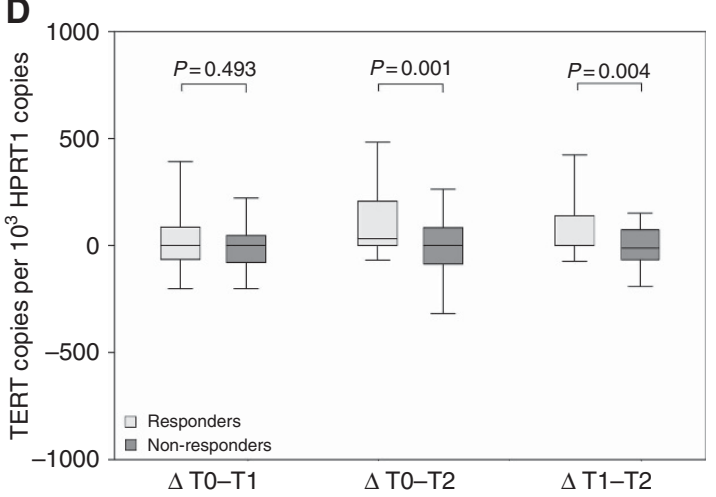

Figure 1. TERT level in responders and non-responders to neoadjuvant therapy. TERT levels in responder and non-responder patients, pre- (TO), during- (T1) and post-CRT (T2), expressed as (A) TERT copies per ml and (B) TERT copies per $10^{3}$ HPRT1 copies. Differences in TERT levels in responders and non-responders, pre- and during ( $\Delta \mathrm{T} 0-\mathrm{T} 1)$, pre- and post- $(\Delta T 0-\mathrm{T} 2)$, during and post CRT( $\Delta T 1-\mathrm{T} 2)$, expressed as $(C) \mathrm{TERT}$ copies per $\mathrm{ml}$ and (D) TERT copies per $10^{3}$ HPRT1 copies. Boxes and whiskers: 25-75th and 10-90th percentiles, respectively; central line in boxes: median. TERT=telomerase reverse transcriptase.

those in non-responders $(0(0-40)$ copies per $\mathrm{ml} v s 162(10-283)$ copies per ml, $P<0.0001$ ) (Figure $1 \mathrm{~A}$ ).

The results obtained when TERT levels were normalised for HPRT1 were comparable. TERT levels were 90 (0-270), 20 (0-140) and $0(0-50)$ copies per $10^{3}$ HPRT1 copies at T0, T1 and at T2, respectively $(P<0.0001)$ in responders, and $80(0-200), 50(0-170)$ and $90(10-190)$ copies per $10^{3}$ HPRT1 copies at T0, T1 and at T2, respectively $(P=0.814)$ in non-responders (Figure $1 \mathrm{~B})$. At T2, the difference between the two groups was highly significant $(0(0-50)$ copies per $10^{3}$ HPRT 1 copies vs $90(10-190)$ copies per $10^{3}$ HPRT1 copies, $P<0.0001)$ ) (Figure 1B).

The differences in the TERT levels between pre- and during CRT $(\Delta \mathrm{T} 0-\mathrm{T} 1)$, during and post-CRT $(\Delta \mathrm{T} 1-\mathrm{T} 2)$ and pre- and post-CRT $(\Delta \mathrm{T} 0-\mathrm{T} 2)$ time points in the responders and the nonresponders are outlined in Figure $1 \mathrm{C}$; the differences between the groups were significant for $\Delta \mathrm{T} 0-\mathrm{T} 2(109(0-241) v s-20(-148$ to 84$)$ copies per $\mathrm{ml}, P<0.0001)$ and $\Delta \mathrm{T} 1-\mathrm{T} 2(5(0-170)$ vs -12 $(-109$ to 40$)$ copies per $\mathrm{ml}, P=0.0011)$. Similar results were obtained when TERT levels were normalised for the HPRT1 (Figure 1D).

Notably, total cell-free RNA significantly decreased only in responders: the estimated levels were $1466(789-2491) \mathrm{pg} \mathrm{ml}^{-1}$, 1066 (515-1824) $\mathrm{pg} \mathrm{ml}^{-1}$ and 591 (277-1126) $\mathrm{pg} \mathrm{ml}^{-1}$ $(P<0.0001)$ at T0, T1 and T2, respectively, in responders, and 1669 (960-2448) $\mathrm{pg} \mathrm{ml}^{-1}, 1414(750-2452) \mathrm{pg} \mathrm{ml}^{-1}$ and 1689 (756-3068) $\mathrm{pg} \mathrm{ml}^{-1}(P=0.1091)$ at T0, T1 and T2, respectively, in non-responders. Although cell-free RNA levels did not differ in the two groups at T0 $(P=0.8607)$, they were statistically different at T2 $(P<0.0001)$.

Carcinoembryonic antigen levels were not statistically different between responders and non-responders, neither pre-CRT (median (IQR) $1.8 \quad(1.0-3.2) \quad v s \quad 2.2 \quad(1.2-4.08) \quad \mathrm{ng} \mathrm{ml}^{-1}$, $P=0.1089)$ nor post-CRT (median (IQR) $1.6(1-2.21)$ vs 1.6 (1.1-2.55) $\left.\mathrm{ng} \mathrm{ml}^{-1}, P=0.3355\right)$.

Prediction of tumour response to neoadjuvant therapy. Age, TERT level at T2 and TERT $\Delta \mathrm{T} 0-\mathrm{T} 2$ were found to be significant predictors of tumour response at univariate analysis and CTNM tended to be significant $(P=0.0591)$ (Table 1$)$. Notably, the TERT level at T2 was predictive of response, both with regard to its median level and its detection $(>0)$ or not detection $(=0)$ (Table 1).

The ROC analysis showed that the TERT value at T2 that best discriminated between the responders and the non-responders was 90 copies per $\mathrm{ml}$; with this cut-off value, the sensitivity and specificity of the assay were $91 \%$ (95\% CI $81-97 \%)$ and $67 \%(95 \%$ CI 56-76\%), respectively, with an AUC of 0.78 (95\% CI 0.71-0.85) (Supplementary Figure 1A).

Carcinoembryonic antigen levels significantly decreased in both responders and non-responders, and CEA levels at both T0 (preCRT) and T2 (post-CRT) time points lacked any predictive value of tumour response to neoadjuvant therapy with an AUC of 0.57 (36\% (95\% CI 24-47\%) sensitivity, 79\% (95\% CI $44-66 \%)$ specificity), and 0.55 (44\% (95\% CI 32-57\%) sensitivity, 66\% (95\% CI 55-76\%) specificity), respectively.

As prediction of tumour response after neoadjuvant therapy may also have clinical implications (with regard to alternative approaches to standard surgery, e.g., transanal local excision or observation), a multiple analysis was performed using factors that were available before surgery. It was found that TERT levels at T2 time point and TERT $\Delta \mathrm{T} 0-\mathrm{T} 2$ independently predicted tumour response (Table 2). When the T2 TERT levels were undetectable or 
Table 1. Univariate logistic regression analysis indicating associations between covariates of interest and tumour response to neoadjuvant therapy

\begin{tabular}{|c|c|c|c|c|c|}
\hline & $\begin{array}{c}\text { Responders/ } \\
N\end{array}$ & $\%$ & OR & $95 \% \mathrm{Cl}$ & $P$-value \\
\hline Age (years) & & & 1.03 & $1.00 ; 1.06$ & 0.0478 \\
\hline $\begin{array}{l}\text { Gender } \\
\text { Female } \\
\text { Male }\end{array}$ & $\begin{array}{l}25 / 54 \\
49 / 122\end{array}$ & $\begin{array}{l}46.3 \\
40.2\end{array}$ & $\begin{array}{l}1.28 \\
1\end{array}$ & $0.67 ; 2.45$ & 0.4477 \\
\hline $\begin{array}{l}\text { Distance from anal } \\
\text { verge }(\mathrm{cm})\end{array}$ & & & 0.94 & $0.84 ; 1.06$ & 0.3177 \\
\hline $\begin{array}{l}\text { Total radiotherapy } \\
\text { dose (Gy) } \\
<50.40 \\
50.40 \\
>50.40\end{array}$ & $\begin{array}{l}11 / 24 \\
39 / 91 \\
18 / 49\end{array}$ & $\begin{array}{l}45.8 \\
42.9 \\
36.7\end{array}$ & $\begin{array}{l}1.46 \\
1.29 \\
1\end{array}$ & $\begin{array}{l}0.54 ; 3.93 \\
0.63 ; 2.64\end{array}$ & $\begin{array}{l}0.4564 \\
0.4823\end{array}$ \\
\hline $\begin{array}{l}\text { Interval between } \\
\text { CRT and surgery } \\
\text { (days) }\end{array}$ & & & 0.99 & $0.79 ; 1.25$ & 0.9551 \\
\hline $\begin{array}{l}\text { Fluoropyrimidine } \\
\text { Alone } \\
\text { +other drugs } \\
\text { No }\end{array}$ & $\begin{array}{c}42 / 94 \\
25 / 68 \\
2 / 6\end{array}$ & $\begin{array}{l}44.7 \\
36.8 \\
33.3\end{array}$ & $\begin{array}{l}1.39 \\
1 \\
0.86\end{array}$ & $\begin{array}{l}0.73 ; 2.63 \\
0.15 ; 5.04\end{array}$ & $\begin{array}{l}0.3133 \\
0.8672\end{array}$ \\
\hline $\begin{array}{c}\text { CTNM } \\
|-| \mid \\
I I \mid\end{array}$ & $\begin{array}{l}15 / 25 \\
58 / 147\end{array}$ & $\begin{array}{l}60.0 \\
39.5\end{array}$ & $\begin{array}{l}2.30 \\
1\end{array}$ & $0.97 ; 5.47$ & 0.0591 \\
\hline $\begin{array}{l}\text { TERT TO } \\
>\text { median } \\
\leqslant \text { median }\end{array}$ & $\begin{array}{l}39 / 87 \\
34 / 88\end{array}$ & $\begin{array}{l}44.8 \\
38.6\end{array}$ & $\begin{array}{l}1.29 \\
1\end{array}$ & $0.71 ; 2.36$ & 0.4066 \\
\hline $\begin{array}{l}\text { TERT T1 } \\
\quad \leqslant \text { median } \\
>\text { median }\end{array}$ & $\begin{array}{l}28 / 59 \\
22 / 58\end{array}$ & $\begin{array}{l}47.5 \\
37.9\end{array}$ & $\begin{array}{l}1.48 \\
1\end{array}$ & $0.71 ; 3.09$ & 0.2985 \\
\hline $\begin{array}{l}\text { TERT } \Delta \text { TO-T1 } \\
\quad>0 \\
\quad \leqslant 0\end{array}$ & $\begin{array}{l}21 / 43 \\
28 / 73\end{array}$ & $\begin{array}{l}48.8 \\
38.4\end{array}$ & $\begin{array}{l}1.53 \\
1\end{array}$ & $0.72 ; 3.29$ & 0.2708 \\
\hline $\begin{array}{l}\text { TERT T2 } \\
\quad=0 \\
>0\end{array}$ & $\begin{array}{l}48 / 69 \\
18 / 84\end{array}$ & $\begin{array}{l}69.6 \\
21.4\end{array}$ & $\begin{array}{l}8.38 \\
1\end{array}$ & $4.03 ; 17.41$ & $<0.0001$ \\
\hline $\begin{array}{l}\text { TERT T2 } \\
\quad \leqslant \text { median } \\
>\text { median }\end{array}$ & $\begin{array}{l}51 / 77 \\
15 / 76\end{array}$ & $\begin{array}{l}66.2 \\
19.7\end{array}$ & $\begin{array}{l}7.98 \\
1\end{array}$ & $3.82 ; 16.66$ & $<0.0001$ \\
\hline $\begin{array}{l}\text { TERT } \Delta \text { TO-T2 } \\
\quad>0 \\
\quad \leqslant 0\end{array}$ & $\begin{array}{l}41 / 70 \\
24 / 82\end{array}$ & $\begin{array}{l}58.6 \\
29.3\end{array}$ & $\begin{array}{l}3.42 \\
1\end{array}$ & $1.74 ; 6.69$ & 0.0003 \\
\hline $\begin{array}{l}\text { CEA TO } \\
\quad \leqslant \text { median } \\
>\text { median }\end{array}$ & $\begin{array}{l}39 / 86 \\
34 / 84\end{array}$ & $\begin{array}{l}45.3 \\
40.5\end{array}$ & $\begin{array}{l}1.22 \\
1\end{array}$ & $0.66 ; 2.24$ & 0.5213 \\
\hline $\begin{array}{l}\text { CEA T2 } \\
\quad \leqslant \text { median } \\
>\text { median }\end{array}$ & $\begin{array}{l}35 / 79 \\
28 / 70\end{array}$ & $\begin{array}{l}44.3 \\
40.0\end{array}$ & $\begin{array}{l}1.19 \\
1\end{array}$ & $0.62 ; 2.29$ & 0.5957 \\
\hline $\begin{array}{l}\text { CEA } \Delta \mathrm{TO} 0-\mathrm{T} 2 \\
\quad \leqslant 0 \\
\quad>0\end{array}$ & $\begin{array}{l}24 / 52 \\
39 / 97\end{array}$ & $\begin{array}{l}46.1 \\
40.2\end{array}$ & $\begin{array}{l}1.27 \\
1\end{array}$ & $0.65 ; 2.51$ & 0.4840 \\
\hline
\end{tabular}

Abbreviations: $\mathrm{CEA}=$ carcinoembryonic antigen; $\mathrm{Cl}=$ confidence inteval; $\mathrm{CRT}=$ chemoradiotherapy; cTNM= clinical Tumour, Node, Metastasis classification; OR=odds ratio; TERT = telomerase reverse transcriptase. Notes: Median levels of TERT were 148, 98 and 42 copies per $\mathrm{ml}$ at T0, T1 and T2 time point, respectively. Median levels of CEA were 2.0 and $1.6 \mathrm{ng} \mathrm{ml}^{-1}$ a T0 and T2 time point, respectively.

below the median level, the OR of tumour response was $7.84(95 \%$ CI 3.64-16.87, $P<0.0001)$ and $8.32 \quad(95 \%$ CI $3.80-18.20$, $P<0.0001$ ), respectively (Table 2 ). The diagnostic performance of the prediction model, assessed by the ROC curve, had an AUC of 0.80 (95\% CI 0.73-0.87) (Table 2 and Supplementary Figure 1B).

Prognostic value of TERT levels for PFS. TERT levels at T3 (4-8 months after surgery) were available for 102 patients. The pTNM stage, TRG score and TERT levels at T2 and at T3 time points were
Table 2. Multiple logistic regression analysis indicating associations between covariates of interest and tumour response to neoadjuvant therapy

$$
\begin{array}{l|l|l|l}
\text { OR } & 95 \% \mathrm{Cl} & P \text {-value } & \text { AUC }
\end{array}
$$

Model based on TERT detection or no detection at the T2 time point

\begin{tabular}{|c|c|c|c|c|c|}
\hline Age (years) & & & & NS & \\
\hline cTNM & $\begin{array}{l}\text { I-II } \\
\text { III }\end{array}$ & & & NS & \\
\hline TERT T2 & $\begin{array}{l}=0 \\
>0\end{array}$ & $\begin{array}{c}7.84 \\
1\end{array}$ & $3.64 ; 16.87$ & $<0.0001$ & \multirow[t]{2}{*}{$\begin{array}{c}0.79(95 \% \\
\mathrm{Cl}: 0.73 ; 0.86)\end{array}$} \\
\hline TERT $\Delta$ T0-T2 & $\begin{array}{l}>0 \\
\leqslant 0\end{array}$ & $\begin{array}{c}2.42 \\
1\end{array}$ & $1.13 ; 5.20$ & 0.0236 & \\
\hline
\end{tabular}

Model based on TERT $>$ median or $\leqslant$ median level at the T2 time point

\begin{tabular}{|c|c|c|c|c|c|}
\hline Age (years) & & & & NS & \\
\hline cTNM & $\begin{array}{l}|-| \mid \\
|| \mid\end{array}$ & & & NS & \\
\hline TERT T2 & $\begin{array}{l}\leqslant \text { median } \\
>\text { median }\end{array}$ & $\begin{array}{c}8.32 \\
1\end{array}$ & $3.80 ; 18.20$ & $<0.0001$ & \multirow[t]{2}{*}{$\begin{array}{c}0.80(95 \% \mathrm{Cl}: \\
0.73 ; 0.87)\end{array}$} \\
\hline TERT $\Delta$ T0-T2 & $\begin{array}{l}>0 \\
\leqslant 0\end{array}$ & $\begin{array}{c}2.64 \\
1\end{array}$ & $1.23 ; 5.67$ & 0.0130 & \\
\hline \multicolumn{6}{|c|}{$\begin{array}{l}\text { Abbreviations: } \mathrm{AUC}=\text { area under curve; } \mathrm{Cl}=\text { confidence interval; } \mathrm{cTNM}=\text { clinical tumour, } \\
\text { node, metastasis classification; } \mathrm{NS}=\text { not significant; } \mathrm{OR}=\text { odds ratio; TERT = telomerase } \\
\text { reverse transcriptase. }\end{array}$} \\
\hline
\end{tabular}

significantly associated with PFS in the univariate analysis (Table 3). The patients' PFS curves according circulating plasma TERT levels are shown in Figure 2. At a median follow-up of 61.2 months, the 5-year PFS of the patients with detectable $(>0)$ or undetectable $(=0)$ T2 TERT levels were $58.8 \%$ (95\%CI 47.1-68.7) and $79.9 \%$ (95\% CI 67.8-87.8), respectively $(P=0.0008$, Table 3 and Figure 2A), and with T2 TERT levels $>$ or $\leqslant$ median level were 59.2\% (95\% CI 47.0-69.4) and $77.6 \%$ (95\% CI 65.9-85.7), respectively ( $P=0.0030$, Table 3 and Figure 2B). The 5 -year PFS of the patients with detectable or undetectable T3 TERT levels were $53.1 \%$ (95\% CI 37.6-66.3) and 90.6\% (95\% CI 76.6-96.4), respectively $(P<0.0001$, Table 3 and Figure 2C). PFS curves according to $\mathrm{pTNM}$ and TGR scores are shown in Supplementary Figure 2A and 2B. Notably, the CEA levels after surgery (CEA T3), but not those before surgery (CEA T2), had a prognostic value (Table 3 and Supplementary Figure 2C).

The results of multiple logistic regression analysis with biological markers after CRT and prior surgery (T2), performed in the 147 patients for whom all data were available, showed that pTNM and TERT were independent prognostic factors of disease progression. Multiple analysis of biological markers 4-8 months after surgery (T3) in the 92 patients for whom all data were available disclosed that pTNM, TERT and CEA maintained their independent prognostic role (Table 4). Detection of TERT at T2 and T3 time points was associated with a risk of disease progression of 2.13 (95\% CI 1.10-4.11)-fold and 4.55 (95\% CI 1.48-13.95)-fold higher, respectively, with respect to patients with undetectable circulating TERT (Table 4).

\section{DISCUSSION}

Circulating cell-free nucleic acids constitute minimally invasive 'liquid biopsies' that are potentially useful for formulating cancer diagnosis, monitoring disease progression and guiding therapeutic decisions (Gingras et al, 2015; Lewis et al, 2015; Alix-Panabières and Pantel, 2016). The finding that TERT is activated in most tumours has opened new fields in cancer research. The results of the present study confirm the findings of a previous one showing 
Table 3. Univariate Cox regression analysis indicating associations between covariates of interest and PFS

\begin{tabular}{|c|c|c|c|c|c|c|c|}
\hline & Events/N & $\%$ & 5 -Years PFS $(95 \% \mathrm{Cl})$ & Log-rank $P$-value & HR & $95 \% \mathrm{Cl}$ & $P$-value \\
\hline Age (years) & & & & & 0.98 & $0.96 ; 1.01$ & 0.2682 \\
\hline $\begin{array}{l}\text { Gender } \\
\text { Male } \\
\text { Female }\end{array}$ & $\begin{array}{c}38 / 120 \\
18 / 54\end{array}$ & $\begin{array}{l}31.7 \\
33.3\end{array}$ & $\begin{array}{l}68.4(59.0 ; 76.2) \\
67.2(52.6 ; 78.2)\end{array}$ & 0.9901 & $\begin{array}{c}1 \\
1.00\end{array}$ & $0.57 ; 1.76$ & 0.9913 \\
\hline Distance from anal verge $(\mathrm{cm})$ & & & & & 0.98 & $0.89 ; 1.09$ & 0.7270 \\
\hline $\begin{array}{l}\text { Total radiotherapy dose (Gy) } \\
\quad<50.40 \\
50.40 \\
>50.40\end{array}$ & $\begin{array}{l}7 / 24 \\
27 / 91 \\
20 / 49\end{array}$ & $\begin{array}{l}29.2 \\
29.7 \\
40.8\end{array}$ & $\begin{array}{l}67.9(43.6 ; 83.5) \\
71.7(61.0 ; 79.9) \\
58.5(42.7 ; 71.3)\end{array}$ & 0.1816 & $\begin{array}{c}1 \\
0.78 \\
1.35\end{array}$ & $\begin{array}{l}0.35 ; 1.80 \\
0.57 ; 3.19\end{array}$ & $\begin{array}{l}0.5594 \\
0.4962\end{array}$ \\
\hline $\begin{array}{l}\text { Fluoropyrimidine } \\
\text { Alone } \\
\text { +other drugs } \\
\text { No }\end{array}$ & $\begin{array}{c}33 / 94 \\
18 / 68 \\
3 / 6\end{array}$ & $\begin{array}{l}35.1 \\
26.5 \\
50.0\end{array}$ & $\begin{array}{c}63.2(52.0 ; 72.5) \\
76.1(64.0 ; 84.6) \\
33.3(1.4 ; 75.5)\end{array}$ & 0.1460 & $\begin{array}{c}1.63 \\
1 \\
2.55\end{array}$ & $\begin{array}{l}0.91 ; 2.94 \\
0.74 ; 8.75\end{array}$ & $\begin{array}{l}0.1002 \\
0.1375\end{array}$ \\
\hline $\begin{array}{c}\text { PTNM } \\
0-\| \\
\| I-I V\end{array}$ & $\begin{array}{c}27 / 126 \\
26 / 39\end{array}$ & $\begin{array}{l}21.4 \\
66.7\end{array}$ & $\begin{array}{l}78.7(70.1 ; 85.2) \\
35.9(21.4 ; 50.6)\end{array}$ & $<0.0001$ & $\begin{array}{c}1 \\
4.35\end{array}$ & $2.51 ; 7.54$ & $<0.0001$ \\
\hline $\begin{array}{l}\text { TRG } \\
\text { Response } \\
\text { No response }\end{array}$ & $\begin{array}{c}15 / 73 \\
41 / 101\end{array}$ & $\begin{array}{l}20.5 \\
40.6\end{array}$ & $\begin{array}{l}78.2(66.3 ; 86.3) \\
60.0(49.2 ; 69.1)\end{array}$ & 0.0047 & $\begin{array}{c}1 \\
2.30\end{array}$ & $1.27 ; 4.17$ & 0.0060 \\
\hline $\begin{array}{l}\text { TERT T2 } \\
\quad=0 \\
>0\end{array}$ & $\begin{array}{l}13 / 69 \\
36 / 83\end{array}$ & $\begin{array}{l}18.8 \\
43.4\end{array}$ & $\begin{array}{l}79.9(67.8 ; 87.8) \\
58.8(47.1 ; 68.7)\end{array}$ & 0.0008 & $\begin{array}{c}1 \\
2.83\end{array}$ & $1.50 ; 5.34$ & 0.0013 \\
\hline $\begin{array}{l}\text { TERT T2 } \\
\quad \leqslant \text { median } \\
>\text { median }\end{array}$ & $\begin{array}{l}16 / 77 \\
33 / 75\end{array}$ & $\begin{array}{l}20.8 \\
44.0\end{array}$ & $\begin{array}{l}77.6(65.9 ; 85.7) \\
59.2(47.0 ; 69.4)\end{array}$ & 0.0030 & $\begin{array}{c}1 \\
2.40\end{array}$ & $1.32 ; 4.37$ & 0.0040 \\
\hline $\begin{array}{l}\text { CEA T2 } \\
\quad \leqslant \text { median } \\
>\text { median }\end{array}$ & $\begin{array}{l}24 / 79 \\
16 / 69\end{array}$ & $\begin{array}{l}30.4 \\
23.2\end{array}$ & $\begin{array}{l}67.3(55.0 ; 76.8) \\
76.9(64.5 ; 85.4)\end{array}$ & 0.3684 & $\begin{array}{c}1 \\
0.75\end{array}$ & $0.40 ; 1.41$ & 0.3700 \\
\hline $\begin{array}{l}\text { TERT T3 } \\
\quad=0=\text { median } \\
\quad>0\end{array}$ & $\begin{array}{c}4 / 52 \\
22 / 50\end{array}$ & $\begin{array}{c}7.7 \\
44.0\end{array}$ & $\begin{array}{l}90.6(76.6 ; 96.4) \\
53.1(37.6 ; 66.3)\end{array}$ & $<0.0001$ & $\begin{array}{c}1 \\
7.46\end{array}$ & $2.56 ; 21.6$ & 0.0002 \\
\hline $\begin{array}{l}\text { CEA T3 } \\
\quad \leqslant \text { median } \\
>\text { median }\end{array}$ & $\begin{array}{l}7 / 61 \\
20 / 55\end{array}$ & $\begin{array}{l}11.5 \\
36.4\end{array}$ & $\begin{array}{l}86.9(74.4 ; 93.6) \\
60.8(45.7 ; 72.9)\end{array}$ & 0.0016 & $\begin{array}{c}1 \\
3.65\end{array}$ & $1.54 ; 8.64$ & 0.0032 \\
\hline
\end{tabular}

Abbreviations: $\mathrm{CEA}=$ carcinoembryonic antigen; $\mathrm{Cl}=$ confidence interval; $\mathrm{HR}=$ hazard ratio; PFS= progression-free survival; $\mathrm{pTNM}=$ pathological Tumour, Node, Metastasis classification; TERT = telomerase reverse transcriptase; TRG = tumour regression grade. Notes: Median levels of TERT at were 42 copies per $\mathrm{ml}$ and 0 copies per $\mathrm{ml}$ at T2 and T3 time point, respectively. Median levels of CEA were 1.6 and $1.5 \mathrm{ng} \mathrm{ml}^{-1}$ at T2 and T3 time point, respectively.

that plasma TERT mRNA can be considered a predictive marker of tumour response to neoadjuvant therapy in rectal cancer patients (Pucciarelli et al, 2012) and demonstrate, for the first time to our knowledge, its prognostic value of disease progression in such patients.

The expression of TERT is usually absent in non-neoplastic tissues but inappropriately activated in most tumours; its detection can thus be considered a specific marker of an ongoing neoplastic process (Hanahan and Weinberg, 2011). A large number of studies, including our own (Terrin et al, 2007, Rampazzo et al, 2012; Bertorelle et al, 2013; Boscolo-Rizzo et al, 2015; Rampazzo et al, 2017), demonstrated that TERT is a prognostic marker of disease outcome for many types of lymphoid and solid malignancies (Giunco et al, 2015). In addition, it has been demonstrated that circulating TERT levels can be detected in the plasma of colorectal cancer patients (Lledó et al, 2004, Terrin et al 2008) and are significantly correlated with those in tumour specimens (Terrin et al, 2008), thus suggesting that plasma TERT may be a useful non-invasive marker for detecting and monitoring the disease.

The neoadjuvant therapy approach followed by mesorectal excision has become the standard treatment for patients with locally advanced rectal cancer (NCCN guidelines, 2017); however, about $20 \%$ of patients are overtreated (Sauer et al, 2004). Moreover, although $\sim 60 \%$ of patients have a moderate-poor response to this approach, about $20 \%$ of patients show a complete pathologic response, which translates into much better clinical outcomes with respect to non-responders (Maas et al, 2010). In the last years, several prospective studies have suggested organ-sparing approaches for patients with major or complete clinical responses (Habr-Gama et al, 2004; Belluco et al, 2011; Bujko et al, 2013; Pucciarelli et al, 2013; Appelt et al, 2015). The advisability of adjuvant chemotherapy in patients with good response to neoadjuvant therapy continues to be a subject of debate. Given these considerations, there is a strong interest to identify biomarkers that are predictors of tumour response and prognostic of disease outcome in order to improve selection of those patients who could benefit from neoadjuvant or adjuvant treatments, who could avoid surgery altogether or who could be spared unnecessary and toxic treatment. Unfortunately, although many clinical, pathological, and molecular markers have been investigated as predictors of tumour response and prognosis, none of them have gained wide acceptance in clinical practice (Spolverato et al, 2011; Lim et al, 2015). Identifying in this scenario circulating biomarkers predictive of tumour response would be an important step forward in monitoring these patients in a minimally invasive way.

As demonstrated in a previous study (Pucciarelli et al, 2012), plasma TERT levels after completion of CRT (time point T2), but not those at baseline, were strongly predictive of tumour response. The results of the present study, characterised by a larger number of patients and an additional time point, that is, during CRT, have confirmed that TERT is an independent predictive marker and that plasma TERT levels tended to fall in responders, but not in non-responders soon after CRT is 

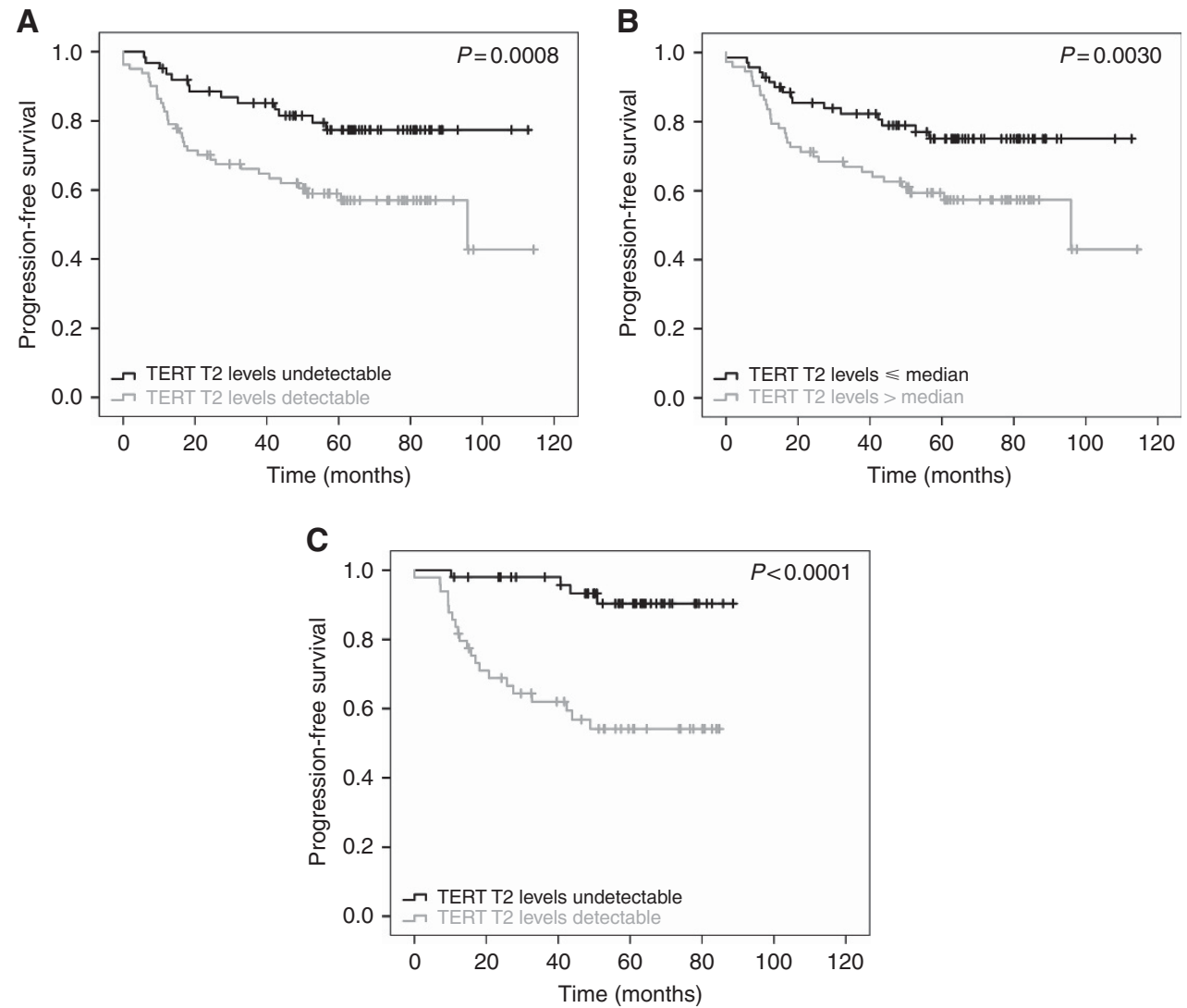

Figure 2. PFS according to TERT level. Kaplan-Meier curves for PFS according to (A) detectable or undetectable TERT T2 level before surgery, (B) TERT T2 levels $\leqslant$ or $>$ median level (42 copies per $\mathrm{ml}$ ) before surgery and (C) detectable or undetectable TERT T3 level after surgery. $\mathrm{PFS}=$ Progression-free survival; TERT=telomerase reverse transcriptase.

initiated. Multiple analysis showed that of the potential predictors available before surgery, post-CRT TERT levels and the variation of prepost CRT TERT levels were independent predictors, with an AUC 0.80 . Models that combined functional imaging with positron emission tomography, clinical data and blood biomarkers (CEA, IL-8 and osteopontin) had an AUC of 0.81 for a complete pathological response, and the model based on biomarkers only had an AUC of $<0.70$ (Buijsen et al, 2014). New studies foreseeing additional assessment time points during CRT and integrating plasma markers (e.g., TERT), endoscopy, imaging modalities and clinical evaluation could lead to greater sensitivity and specificity in managing individual patient.

As regards CEA, several studies, most using $5 \mathrm{ng} \mathrm{ml}^{-1}$ as cutoff, have demonstrated that low levels were associated with a tumour response (Moureau-Zabotto et al, 2011; Tural et al, 2013; Buijesen et al, 2014). Preoperative CEA levels cannot, however, be used to stratify treatment strategies as they lack sensitivity and specificity (Lim et al, 2015). In the present study, neither pre- nor post-CRT CEA levels were able to predict tumour response to neoadjuvant therapy. Only 27 patients had at baseline CEA levels higher than $5 \mathrm{ng} \mathrm{ml}^{-1}$; even using this cut-off, no association was found between CEA levels and tumour response (data not shown).

Of interest, circulating TERT level were also found to an independent prognostic marker of disease outcome. Although pathologic tumour staging is of the utmost importance in rectal cancer patients, it provides only limited prognostic information and the risk of disease progression cannot be foreseen, even in patients at the same tumour stage. This may reflect the molecular and biological heterogeneity of rectal cancers, and highlight the need for prognostic markers able to stratify patients.

Plasma TERT levels, to the best of our knowledge, have never been evaluated as prognostic marker in rectal cancer patients.
Previous studies have indicated that telomerase activity and/or TERT expression rose along with tumour progression in colorectal cancer (Maláska et al, 2004; Terrin et al, 2008; Rampazzo et al, 2010, Kojima et al, 2011), and it is generally agreed that high levels of TERT and/or telomerase activity in tumour specimens are associated with poor prognosis (Bertorelle et al, 2014). Higher levels of TERT may be able to compensate for the greater shortening of telomeres, due to high proliferative activity. Beyond preserving telomere length, TERT might also increase the tumour's malignant potential by acting as a growth-promoting and antiapoptotic factor (Rampazzo et al, 2012; Saretzki, 2014; Celeghin et al, 2016). In a series of colorectal cancers (stage I to stage IV), the plasma TERT levels correlated with those in tumours, both when expressed as copies per $\mathrm{ml}$ and when normalised against HPRT1 (Terrin et al, 2008). The circulating TERT levels may reflect those in the corresponding cancer specimens.

In agreement with other data (Mass et al, 2010; Lim et al, 2015), we observed that patients with a good response to neoadjuvant therapy also had a better prognosis with respect to non-responder patients. The prognostic value of TRG was not, however, confirmed by multiple analysis. In addition, circulating CEA levels quantified several months after surgery, but not those before surgery, had an independent prognostic value. Multiple Cox regression analyses showed that only pathologic staging and plasma TERT levels were independent prognostic factors both at surgery and afterwards. This finding is important as TERT level at the time of surgery could assist in selecting patients who would benefit from adjuvant chemotherapy.

In conclusion, the results of this study have confirmed that levels of TERT and their variations pre-post neoadjuvant therapy are predictive biomarkers of tumour response in rectal cancer patients who undergo CRT. They also showed that TERT levels before and 
Table 4. Multiple Cox regression analysis indicating associations between covariates of interest and progressionfree survival

\begin{tabular}{|c|c|c|c|c|}
\hline & & HR & $95 \% \mathrm{Cl}$ & $P$-value \\
\hline \multicolumn{5}{|c|}{ (A) TERT levels before surgery } \\
\hline \multicolumn{5}{|c|}{ TERT levels $=$ or $>0$} \\
\hline PTNM & $\begin{array}{c}0-\| \\
I I I-I V\end{array}$ & $\begin{array}{c}1 \\
3.70\end{array}$ & $2.04 ; 6.73$ & $<0.0001$ \\
\hline TRG & $\begin{array}{c}\text { Response } \\
\text { No response }\end{array}$ & & & NS \\
\hline TERT T2 & $\begin{array}{l}=0 \\
>0\end{array}$ & $\begin{array}{c}1 \\
2.13\end{array}$ & $1.10 ; 4.11$ & 0.0242 \\
\hline \multicolumn{5}{|c|}{ TERT levels $<$ or $>$ median } \\
\hline pTNM & $\begin{array}{c}0-I I \\
\text { III-IV }\end{array}$ & $\begin{array}{c}1 \\
3.89\end{array}$ & $2.16 ; 7.02$ & $<0.0001$ \\
\hline TRG & $\begin{array}{l}\text { Response } \\
\text { No response }\end{array}$ & & & NS \\
\hline TERT T2 & $\begin{array}{l}\leqslant \text { median } \\
>\text { median }\end{array}$ & $\begin{array}{c}1 \\
2.08 \\
\end{array}$ & $1.12 ; 3.87$ & 0.0212 \\
\hline \multicolumn{5}{|c|}{ (B) TERT levels after surgery } \\
\hline \multicolumn{5}{|c|}{ TERT levels $=$ or $>0$} \\
\hline pTNM & $\begin{array}{c}0-I I \\
I I I-I V\end{array}$ & $\begin{array}{c}1 \\
3.01 \\
\end{array}$ & $1.25 ; 7.28$ & 0.0144 \\
\hline TRG & $\begin{array}{c}\text { Response } \\
\text { No response }\end{array}$ & & & NS \\
\hline TERT T3 & $\begin{array}{c}=0 \text { median } \\
>0\end{array}$ & $\begin{array}{c}1 \\
4.55\end{array}$ & $1.48 ; 13.95$ & 0.0081 \\
\hline CEA T3 & $\begin{array}{l}\leqslant \text { median } \\
>\text { median }\end{array}$ & $\begin{array}{c}1 \\
3.22 \\
\end{array}$ & $1.24 ; 8.35$ & 0.0162 \\
\hline \multicolumn{5}{|c|}{$\begin{array}{l}\text { Abbreviations: } C E A=\text { carcinoembryonic antigen; } \mathrm{Cl}=\text { confidence interval; } H R=\text { hazards } \\
\text { ratio; } p \text { TNM }=\text { pathological tumour, node, metastasis classification; } T E R T=\text { telomerase } \\
\text { reverse transcriptase; } T R G=\text { tumour regression grade. Notes: The models were developed } \\
\text { using TERT levels before surgery (A) or after surgery (B). CEA was included in the model } B \\
\text { because } C E A \text { levels at } T 3 \text { time point were significant in the univariate analysis. }\end{array}$} \\
\hline
\end{tabular}

after surgery are independent prognostic markers of disease outcome. Further studies, including standardised methods of RNA extraction and quantification, and standardised assay(s) to quantify TERT, are important to validate the predictive and prognostic roles of plasma TERT level, and to ascertain its reliability as a circulating biomarker to monitor in a minimally invasive way the response to therapy and the disease outcome in cancer patients.

\section{ACKNOWLEDGEMENTS}

This study was supported by Ricerca Finalizzata Ministero della Salute, Grant number RF-2011-02349645 and Istituto Oncologico Veneto, Grant $5 \times 1000$. RE is a fellow recipient fellow of Grant number RF-2011-02349645

\section{CONFLICT OF INTEREST}

The authors declare no conflict of interest.

\section{REFERENCES}

Alix-Panabières C, Pantel K (2016) Clinical applications of circulating tumor cells and circulating tumor DNA as liquid biopsy. Cancer Discov 6(5): 479-491.

Amin MB, Greene FL, Edge SB, Compton CC, Gershenwald JE, Brookland RK, Meyer L, Gress DM, Byrd DR, Winchester DP. (2017) The Eighth
Edition AJCC Cancer Staging Manual: continuing to build a bridge from a population-based to a more "personalized" approach to cancer staging. CA Cancer J Clin 67(2): 93-99.

Appelt AL, Pløen J, Harling H, Jensen FS, Jensen LH, Jørgensen JC, Lindebjerg J, Rafaelsen SR, Jakobsen A (2015) High-dose chemoradiotherapy and watchful waiting for distal rectal cancer: a prospective observational study. Lancet Oncol 16(8): 919-927.

Beddy D, Hyland JM, Winter DC, Lim C, White A, Moriarty M, Armstrong J, Fennelly D, Gibbons D, Sheahan K (2008) A simplified tumor regression grade correlates with survival in locally advanced rectal carcinoma treated with neoadjuvant chemoradiotherapy. Ann Surg Oncol 15(12): 3471-3477.

Belluco C, De Paoli A, Canzonieri V, Sigon R, Fornasarig M, Buonadonna A, Boz G, Innocente R, Perin T, Cossaro M, Polesel J, De Marchi F (2011) Long-term outcome of patients with complete pathologic response after neoadjuvant chemoradiation for cT3 rectal cancer: implications for local excision surgical strategies. Ann Surg Oncol 18(13): 3686-3693.

Bertorelle R, Briarava M, Rampazzo E, Biasini L, Agostini M, Maretto I, Lonardi S, Friso ML, Mescoli C, Zagonel V, Nitti D, De Rossi A, Pucciarelli S (2013) Telomerase is an independent prognostic marker of overall survival in patients with colorectal cancer. Br J Cancer 108(2): 278-284.

Bertorelle R, Rampazzo E, Pucciarelli S, Nitti D, De Rossi A (2014) Telomeres, telomerase and colorectal cancer. World J Gastroenterol 20(8): 940-1950.

Blackburn EH, Greider CW, Szostak JW (2006) Telomeres and telomerase: the path from maize,Tetrahymena and yeast to human cancer and aging. Nat Med 12: 1133-1138.

Boscolo-Rizzo P, Rampazzo E, Perissinotto E, Piano MA, Giunco S, Baboci L, Spinato G, Spinato R, Tirelli G, Da Mosto MC, Del Mistro A, De Rossi A (2015) Telomere shortening in mucosa surrounding the tumor: biosensor of field cancerization and prognostic marker of mucosal failure in head and neck squamous cell carcinoma. Oral Oncol 51(5): 500-507.

Bosset JF, Collette L, Calais G, Mineur L, Maingon P, Radosevic-Jelic L, Daban A, Bardet E, Beny A, Ollier JC (2006) Chemotherapy with preoperative radiotherapy in rectal cancer. $N$ Engl J Med 355(11): 1114-1123.

Buijsen J, van Stiphout RG, Menheere PP, Lammering G, Lambin P. (2014) Blood biomarkers are helpful in the prediction of response to chemoradiation in rectal cancer: a prospective, hypothesis driven study on patients with locally advanced rectal cancer. Radiother Oncol 111(2): 237-242.

Bujko K, Richter P, Smith FM, Polkowski W, Szczepkowski M, Rutkowski A, Dziki A, Pietrzak L, Kołodziejczyk M, Kuśnierz J, Gach T, Kulig J, Nawrocki G, Radziszewski J, Wierzbicki R, Kowalska T, Meissner W, Radkowski A, Paprota K, Polkowski M, Rychter A (2013) Preoperative radiotherapy and local excision of rectal cancer with immediate radical reoperation for poor responders: a prospective multicentre study. Radiother Oncol 106(2): 198-205.

Celeghin A, Giunco S, Freguja R, Zangrossi M, Nalio S, Dolcetti R, De Rossi A (2016) Short-term inhibition of TERT induces telomere lengthindependent cell cycle arrest and apoptotic response in EBV-immortalized and transformed B cells. Cell Death Dis 7(12): e2562.

Deblakshmi RK, Deka M, Saikia AK, Sharma BK, Singh N, Das NN, Bose S (2015) Prognostic relevance of human telomerase reverse transcriptase (hTERT) expression in patients with gall bladder disease and carcinoma. Asian Pac J Cancer Prev 16(7): 2923-2928.

Edge SB, Compton CC (2010) The American Joint Committee on Cancer: the 7th Edition of the AJCC Cancer Staging Manual and the Future of TNM. Ann Surg Oncol 17(6): 1471-1474.

El-Hefnawy T, Raja S, Kelly L, Bigbee WL, Kirkwood JM, Luketich JD (2004) Characterization of amplifiable, circulating RNA in plasma and its potential as a tool for cancer diagnostics. Clin Chem 50(3): 564-573.

Gerard JP, Conroy T, Bonnetain F, Bouche O, Chapet O, Closon-Dejardin MT, Untereiner M, Leduc B, Francois E, Maurel J, Seitz JF, Buecher B, Mackiewicz R, Ducreux M, Bedenne L (2006) Preoperative radiotherapy with or without concurrent fluorouracil and leucovorin in T3-4 rectal cancers: results of FFCD 9203. J Clin Oncol 24(28): 4620-4625.

Gingras I, Salgado R, Ignatiadis M (2015) Liquid biopsy: will it be the 'magic tool' for monitoring response of solid tumors to anticancer therapies? Curr Opin Oncol 27(6): 560-567.

Giunco S, Rampazzo E, Celeghin A, Petrara MR, De Rossi A (2015) Telomere and telomerase in carcinogenesis: their role as prognostic biomarkers. Curr Pathobiol Rep 3(4): 315-328.

Habr-Gama A, Perez RO, Nadalin W, Sabbaga J, Ribeiro Jr U, Silva e Sousa Jr AH, Campos FG, Kiss DR, Gama-Rodrigues J (2004) Operative versus nonoperative treatment for stage 0 distal rectal cancer following chemoradiation therapy: long-term results. Ann Surg 240(4): 711-717. 
Hanahan D, Weinberg RA (2011) Hallmarks of cancer: the next generation. Cell 144(5): 646-674.

Kang Y, Zhang J, Sun P, Shang J (2013) Circulating cell-free human telomerase reverse transcriptase mRNA in plasma and its potential diagnostic and prognostic value for gastric cancer. Int J Clin Oncol 18(3): $478-486$.

Kojima K, Hiyama E, Otani K, Ohtaki M, Fukuba I, Fukuda E, Sueda T, Hiyama K (2011) Telomerase activation without shortening of telomeric 3 '-overhang is a poor prognostic factor in human colorectal cancer. Cancer Sci 102(2): 330-335.

Lewis JM, Heineck DP, Heller MJ (2015) Detecting cancer biomarkers in blood: challenges for new molecular diagnostic and point-of-care tests using cell-free nucleic acids. Expert Rev Mol Diagn 15(9): 1187-1200.

Lim SH, Chua W, Henderson C, Ng W, Shin JS, Chantrill L, Asghari R, Lee CS, Spring KJ, de Souza P (2015) Predictive and prognostic biomarkers for neoadjuvant chemoradiotherapy in locally advanced rectal cancer. Crit Rev Oncol Hematol 96(1): 67-80.

Lin D, Wei LJ, Ying Z (1993) Checking the Cox model with cumulative sums of Martingale-based residuals. Biometrika 80: 557-572.

Lledó SM, Garcia-Granero E, Dasí F, Ripoli R, García SA, Cervantes A, Aliño SF (2004) Real time quantification in plasma of human telomerase reverse transcriptase (hTERT) mRNA in patients with colorectal cancer. Colorectal Dis 6(4): 236-242.

Maas M, Nelemans PJ, Valentini V, Das P, Rödel C, Kuo LJ, Calvo FA, GarcíaAguilar J, Glynne-Jones R, Haustermans K, Mohiuddin M, Pucciarelli S, Small Jr W, Suárez J, Theodoropoulos G, Biondo S, Beets-Tan RG, Beets GL (2010) Long-term outcome in patients with a pathological complete response after chemoradiation for rectal cancer: a pooled analysis of individual patient data. Lancet Oncol 11(9): 835-844.

Maláska J, Kunická Z, Borský M, Sklenicková M, Novotná M, Fajkusová L, Zaloudík J, Fajkus J (2004) Telomerase as a diagnostic and predictive marker in colorectal carcinoma. Neoplasma 51: 90-96.

Mandard AM, Dalibard F, Mandard JC, Marnay J, Henry-Amar M, Petiot JF, Roussel A, Jacob JH, Segol P, Samama G (1994) Pathologic assessment of tumor regression after preoperative chemoradiotherapy of esophageal carcinoma. Clinicopathologic correlations. Cancer 73(11): 2680-2686.

March-Villalba JA, Martínez-Jabaloyas JM, Herrero MJ, Santamaria J, Aliño SF, Dasí F (2012) Cell-free circulating plasma hTERT mRNA is a useful marker for prostate cancer diagnosis and is associated with poor prognosis tumor characteristics. PLoS ONE 7(8): e43470.

Miura N, Nakamura H, Sato R, Tsukamoto T, Harada T, Takahashi S, Adachi Y, Shomori K, Sano A, Kishimoto Y, Ito H, Hasegawa J, Shiota G (2006) Clinical usefulness of serum telomerase reverse transcriptase (hTERT) mRNA and epidermal growth factor receptor (EGFR) mRNA as a novel tumor marker for lung cancer. Cancer Sci 97(12): 1366-1373.

Moureau-Zabotto L, Farnault B, de Chaisemartin C, Esterni B, Lelong B, Viret F, Giovannini M, Monges G, Delpero JR, Bories E, Turrini O, Viens P, Salem N (2011) Predictive factors of tumor response after neoadjuvant chemoradiation for locally advanced rectal cancer. Int J Radiat Oncol Biol Phys 80(2): 483-491.

NCCN Clinical Practice Guidelines in Oncology - Rectal Cancer Version 3 (2017) https://www.nccn.org/professionals/physician_gls/default.aspx.

Pucciarelli S, Rampazzo E, Briarava M, Maretto I, Agostini M, Digito M, Keppel S, Friso ML, Lonardi S, De Paoli A, Mescoli C, Nitti D, De Rossi A (2012) Telomere-specific reverse transcriptase (hTERT) and cell-free RNA in plasma as predictors of pathologic tumor response in rectal cancer patients receiving neoadjuvant chemoradiotherapy. Ann Surg Oncol 19(9): 3089-3096.

Pucciarelli S, De Paoli A, Guerrieri M, La Torre G, Maretto I, De Marchi F, Mantello G, Gambacorta MA, Canzonieri V, Nitti D, Valentini V, Coco C (2013) Local excision after preoperative chemoradiotherapy for rectal cancer: results of a multicenter phase II clinical trial. Dis Colon Rectum 56(12): 1349-1356.
Rampazzo E, Bertorelle R, Serra L, Terrin L, Candiotto C, Pucciarelli S, Del Bianco P, Nitti D, De Rossi A (2010) Relationship between telomere shortening, genetic instability, and site of tumour origin in colorectal cancers. Br J Cancer 102(8): 1300-1305.

Rampazzo E, Bonaldi L, Trentin L, Visco C, Keppel S, Giunco S, Frezzato F, Facco M, Novella E, Giaretta I, Del Bianco P, Semenzato G, De Rossi A (2012) Telomere length and telomerase levels delineate subgroups of B-cell chronic lymphocytic leukemia with different biological characteristics and clinical outcomes. Haematologica 97(1): 56-63.

Rampazzo E, Bojnik E, Trentin L, Bonaldi L, Del Bianco P, Frezzato F, Visentin A, Facco M, Semenzato G, De Rossi A (2017) Role of $m i R-15 a / m i R-16-1$ and the TP53 axis in regulating telomerase expression in chronic lymphocytic leukemia. Haematologica 102(7): e253-e256.

Roh MS, Colangelo LH, O'Connell MJ, Yothers G, Deutsch M, Allegra CJ, Kahlenberg MS, Baez-Diaz L, Ursiny CS, Petrelli NJ, Wolmark N (2009) Preoperative multimodality therapy improves disease-free survival in patients with carcinoma of the rectum: NSABP R-03. J Clin Oncol 27(31): 5124-5130.

Saretzki G (2014) Extra-telomeric functions of human telomerase: cancer, mitochondria and oxidative stress. Curr Pharm Des 20(41): 6386-6403.

Sauer R, Becker H, Hohenberger W, Rodel C, Wittekind C, Fietkau R, Martus P, Tschmelitsch J, Hager E, Hess CF, Karstens JH, Liersch T, Schmidberger H, Raab R (2004) Preoperative versus postoperative chemoradiotherapy for rectal cancer. N Engl J Med 351(17): 1731-1740.

Siegel R, Desantis C, Jemal A. Colorectal cancer statistics (2014) CA Cancer $J$ Clin 64(2): 104-117.

Spolverato G, Pucciarelli S, Bertorelle R, De Rossi A, Nitti D (2011) Predictive factors of the response of rectal cancer to neoadjuvant radiochemotherapy. Cancers 3(2): 2176-2194.

Spornraft M, Kirchner B, Haase B, Benes V, Pfaffl MW, Riedmaier I (2014) Optimization of extraction of circulating RNAs from plasma-enabling small RNA sequencing. PLOS ONE 9(9): e107259.

Tani N, Ichikawa D, Ikoma D, Tomita H, Sai S, Ikoma H, Okamoto K, Ochiai T, Ueda Y, Otsuji E, Yamagishi H, Miura N, Shiota G (2007) Circulating cell-free mRNA in plasma as a tumor marker for patients with primary and recurrent gastric cancer. Anticancer Res 27(2): $1207-1212$.

Terrin L, Trentin L, Degan M, Corradini I, Bertorelle R, Carli P, Maschio N, Bo MD, Noventa F, Gattei V, Semenzato G, De Rossi A (2007) Telomerase expression in B-cell chronic lymphocytic leukemia predicts survival and delineates subgroups of patients with the same IgVH mutation status and different outcome. Leukemia 21(5): 965-967.

Terrin L, Rampazzo E, Pucciarelli S, Agostini M, Bertorelle R, Esposito G, Del Bianco P, Nitti D, De Rossi A (2008) Relationship between tumor and plasma levels of hTERT mRNA in patients with colorectal cancer: implications for monitoring of neoplastic disease. Clin Cancer Res 14(22): 7444-7451.

Torre LA, Siegel RL, Ward EM, Jemal A (2016) Global cancer incidence and mortality rates and trends-an update. Cancer Epidemiol Biomarkers Prev 25(1): 16-27.

Tural D, Selcukbiricik F, Özturk MA, Yildiz O, Turna H, Erdamar S, Büyükünal E, Serdengeçti S (2013) The relation between pathological complete response and clinical outcome in patients with rectal cancer. Hepatogastroenterology 60(126): 1365-1370.

cc)(i) (2) This work is licensed under the Creative Commons (19. ${ }_{\text {BC }}$ Attribution-Non-Commercial-Share Alike 4.0 International License. To view a copy of this license, visit http:// creativecommons.org/licenses/by-nc-sa/4.0/

(C) The Author(s) named above 2018

Supplementary Information accompanies this paper on British Journal of Cancer website (http://www.nature.com/bjc) 